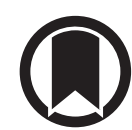

CrossMark

\title{
Universal use of face masks for success against COVID-19: evidence and implications for prevention policies
}

\author{
To the Editor:
}

A debate is taking place on the use of face masks (both cloth and surgical) as a prevention tool in the community vis à vis the recent World Health Organization (WHO) recommendations. To shed light on this important topic, we reviewed relevant literature, focusing on the keywords "infection control", "prevention", "masks", "respirators", "viral infections" and "COVID-19", without time restrictions to identify a minimum set of references from an electronic database (PUBMED), existing guidelines, viral diseases, airborne diseases and grey literature.

The core findings of the references identified are summarised in table 1.

According to the WHO report published in February 2020, the proportion of truly asymptomatic carriers of severe acute respiratory syndrome coronavirus 2 (SARS-CoV-2) infection was relatively small and was not a major driver of virus circulation, infection transmission and new disease development [15]. However, in blanket testing of an isolated village of 3000 people in northern Italy, 50-75\% of people with positive pharyngeal molecular tests were totally asymptomatic [1]. This finding was echoed by a more recent daily surveillance report from China, where all people arriving from overseas were rigorously tested: among 166 persons with newly identified infections, 78\% were asymptomatic [2]. Although the infective dose associated with transmission is not known, the viral load in the respiratory tract in an asymptomatic patient has been reported to be similar to patients with symptoms [3], and transmission of SARS-CoV-2 infection from an asymptomatic contact has also been described [4].

Until recently, it was thought that the virus could only be transmitted by droplets that are coughed or sneezed out or by contaminated fomites, with differences according to the initial load and surface characteristics [5]. Airborne transmission of SARS-CoV-2 was considered possible only when care procedures generating aerosols (e.g. intubation, bronchoscopy and positive-pressure ventilation) were performed [6]. However, other studies seemed to indicate the opposite, i.e. that the virus is present in exhaled air produced by talking and breathing [6]. Moreover, a potential role for aerosols in virus diffusion was evident in a complex laboratory study. Aerosols containing a viral load quite similar to that observed in human respiratory samples were created to generate an aerosolised environment. SARS-CoV-2 was detected $\leqslant 3 \mathrm{~h}$ after the start of the study [7]. Although these findings were not considered fully convincing by some authors [5], they deserve attention and further studies are required to establish whether and when airborne transmission of SARS-CoV-2 truly occurs and how it can be reduced.

It is well known that surgical masks can prevent the inhalation of large droplets and sprays but have limited ability to filter submicron-sized airborne particles $[8,9]$. As SARS-CoV-2 is also embedded in aerosols $<5 \mu \mathrm{m}$ in diameter, it cannot be determined whether they are always effective. However, mask wearing by patients with pulmonary tuberculosis (an airborne infectious disease) has been shown to reduce infectivity to guinea pigs by $56 \%[9,10]$. The surgical mask has also been shown to intercept other human coronaviruses during coughing [11]. A meta-analysis of randomised controlled trials has also shown that surgical masks and N95 respirators were similarly effective in preventing influenza-like illness and laboratory-confirmed influenza among healthcare workers [12]. Similar results were obtained in a case-control study comparing the protective effect of surgical masks and N95 respirators against SARS among healthcare workers in five Hong Kong hospitals [13].

@ERSpublications

Cloth masks are a simple, economic and sustainable alternative to surgical masks as a means of source control of SARS-CoV-2 in the general community https://bit.ly/2x2xTL4

Cite this article as: Esposito S, Principi N, Leung CC, et al. Universal use of face masks for success against COVID-19: evidence and implications for prevention policies. Eur Respir J 2020; 55: 2001260 [https://doi.org/10.1183/13993003.01260-2020]. 
TABLE 1 Main studies on severe acute respiratory syndrome coronavirus 2 (SARS-CoV-2) transmission

\begin{tabular}{|lll}
$\begin{array}{c}\text { First author/ } \\
\text { institution } \\
\text { [ref.] }\end{array}$ & Setting & Study \\
\hline DAY [1] & $\begin{array}{c}\text { Vo' Euganeo, } \\
\text { Italy }\end{array}$ & $\begin{array}{r}\text { RNA testing of the entire village } \\
\text { population (3000 inhabitants) }\end{array}$ \\
\hline
\end{tabular}

Main findings and comments

DAY [2] China Screening of overseas arrivals

$50-75 \%$ of infected individuals were asymptomatic, representing "a formidable source" of contagion. Isolation of asymptomatic individuals was essential for controlling virus spread and epidemic seriousness.

$130(78 \%)$ of 166 new infections identified in the 24-h period to the afternoon of Wednesday 1 April 2020 were asymptomatic.

Asymptomatic infections would not be able to cause another major outbreak of COVID-19 if such individuals were kept in isolation.

\begin{tabular}{|c|c|c|}
\hline Zou[3] & $\begin{array}{l}\text { Zhuhai, } \\
\text { Guangdong, } \\
\text { China }\end{array}$ & $\begin{array}{l}\text { Monitoring SARS-CoV-2 viral } \\
\text { loads in the upper respiratory } \\
\text { specimens of } 18 \text { patients }\end{array}$ \\
\hline
\end{tabular}
Higher viral loads were detected soon after symptom onset and the viral load in an asymptomatic patient was similar to that in symptomatic patients.

$\begin{array}{lll}\text { Rothe[4] } & \begin{array}{c}\text { Munich, } \\ \text { Germany }\end{array} & \begin{array}{c}\text { Report of transmission of } \\ \text { COVID-19 from an } \\ \text { asymptomatic individual to } \\ \text { four contacts }\end{array} \\ \text { WHO [5] } & \text { Global } & \text { Precaution recommendations }\end{array}$

The fact that asymptomatic persons are a potential source of COVID-19 infection may warrant a reassessment of the transmission dynamics of the current outbreak.

The routes of COVID-19 transmission are via droplet, fomites and airborne transmission of droplet nuclei $(<5 \mu \mathrm{m})$, with less evidence of intestine transmission. WHO continues to recommend droplet and contact precautions and not airborne precautions.

\begin{tabular}{|c|c|c|c|}
\hline LeWIS [6] & Global & $\begin{array}{l}\text { Reporting of different } \\
\text { viewpoints }\end{array}$ & $\begin{array}{l}\text { Arguments in favour of and against } \\
\text { airborne transmission and related } \\
\text { prevention are discussed. }\end{array}$ \\
\hline $\begin{array}{l}\text { van Doremalen } \\
\text { [7] }\end{array}$ & USA & $\begin{array}{l}\text { The stability of SARS-CoV-2 and } \\
\text { SARS-CoV-1 in aerosols and } \\
\text { on various surfaces was } \\
\text { evaluated and their decay } \\
\text { rates were estimated using a } \\
\text { Bayesian regression model }\end{array}$ & $\begin{array}{l}\text { Aerosol and fomite transmission of } \\
\text { SARS-CoV- } 2 \text { is plausible, as the } \\
\text { virus can remain viable and } \\
\text { infectious in aerosols for hours } \\
\text { and on surfaces up to days. }\end{array}$ \\
\hline $\begin{array}{l}\text { University of } \\
\text { Maryland [8] }\end{array}$ & Global & & $\begin{array}{l}\text { Wearing surgical masks in public } \\
\text { could help slow COVID-19 } \\
\text { pandemic's advance; masks may } \\
\text { limit the spread of diseases, } \\
\text { including influenza, rhinoviruses } \\
\text { and coronaviruses. }\end{array}$ \\
\hline MIGLIORI[9] & Europe & WHO consensus document & $\begin{array}{l}\text { The core components of infection } \\
\text { control are discussed, together } \\
\text { with precautions for preventing } \\
\text { unnecessary admissions, with a } \\
\text { focus on TB. The importance of } \\
\text { personal protection (respirators to } \\
\text { protect healthcare staff, other } \\
\text { patients and visitors, and surgical } \\
\text { masks for infectious patients) is } \\
\text { discussed. }\end{array}$ \\
\hline
\end{tabular}




\section{TABLE 1 Continued}

$\begin{aligned} & \text { First author/ Setting Study Main findings and comments } \\ & \text { institution } \\ & \text { [ref.] }\end{aligned}$

\begin{tabular}{|c|c|c|c|}
\hline $\begin{array}{l}\text { DHARMADHIKARI } \\
\text { [10] }\end{array}$ & South Africa & $\begin{array}{l}17 \text { MDR-TB patients wore face } \\
\text { masks on alternate days. } \\
\text { Ward air was exhausted to } \\
\text { two identical chambers, each } \\
\text { housing } 90 \text { guinea pigs } \\
\text { breathing ward air either } \\
\text { when patients wore surgical } \\
\text { face masks (intervention } \\
\text { group) or when patients did } \\
\text { not wear masks (control } \\
\text { group). }\end{array}$ & $\begin{array}{l}69(76.6 \%) \text { of } 90 \text { control guinea pigs } \\
\text { became infected, compared with } \\
36(40 \%) \text { of } 90 \text { intervention guinea } \\
\text { pigs, representing a } 56 \%(95 \% \mathrm{Cl} \\
33-70.5 \%) \text { decreased risk of TB } \\
\text { transmission when patients used } \\
\text { masks. Surgical face masks on } \\
\text { patients with MDR-TB significantly } \\
\text { reduced transmission and offered } \\
\text { an adjunct measure for reducing } \\
\text { TB transmission from infectious } \\
\text { patients. }\end{array}$ \\
\hline LEung[11] & Hong Kong & $\begin{array}{l}\text { Quantification of the amount of } \\
\text { respiratory virus in exhaled } \\
\text { breath of participants with } \\
\text { medically attended ARIs and } \\
\text { determination of the potential } \\
\text { efficacy of surgical face } \\
\text { masks to prevent respiratory } \\
\text { virus transmission }\end{array}$ & $\begin{array}{l}246 \text { patients were studied. Surgical } \\
\text { face masks significantly reduced } \\
\text { the detection of influenza virus } \\
\text { RNA in respiratory droplets and } \\
\text { coronavirus RNA in aerosols, with } \\
\text { a trend toward reduced detection } \\
\text { of coronavirus RNA in respiratory } \\
\text { droplets. The results indicate that } \\
\text { surgical face masks could prevent } \\
\text { transmission of human } \\
\text { coronaviruses and influenza } \\
\text { viruses from symptomatic } \\
\text { individuals. }\end{array}$ \\
\hline Long[12] & China & $\begin{array}{l}\text { Systematic review and } \\
\text { meta-analysis of the } \\
\text { effectiveness of N95 } \\
\text { respirators versus surgical } \\
\text { masks to prevent influenza }\end{array}$ & $\begin{array}{l}\text { The use of N95 respirators compared } \\
\text { with surgical masks is not } \\
\text { associated with a lower risk of } \\
\text { laboratory-confirmed influenza. It } \\
\text { suggests that N95 respirators } \\
\text { should not be recommended for } \\
\text { the general public and } \\
\text { non-high-risk medical staff (those } \\
\text { are not in close contact with } \\
\text { influenza patients or suspected } \\
\text { patients). }\end{array}$ \\
\hline Seto[13] & Hong Kong & $\begin{array}{l}\text { Case-control study in five } \\
\text { hospitals }\end{array}$ & $\begin{array}{l}241 \text { non-infected and } 13 \text { infected } \\
\text { staff were surveyed regarding their } \\
\text { use of masks, gloves and gowns, } \\
\text { and their hand washing. } 69 \text { staff } \\
\text { who reported the use of all four } \\
\text { measures were not infected, while } \\
\text { all infected staff omitted at least } \\
\text { one measure ( } p=0.0224 \text { ). Fewer } \\
\text { staff who wore masks ( } p=0.0001 \text { ), } \\
\text { gowns ( } p=0.006 \text { ) and washed their } \\
\text { hands ( } p=0.047 \text { ) were infected } \\
\text { compared with those who did not; } \\
\text { stepwise logistic regression was } \\
\text { significant only for masks } \\
\text { ( } p=0.011 \text { ). The practice of droplet } \\
\text { precaution and contact precaution } \\
\text { is adequate in significantly } \\
\text { reducing the risk of infection after } \\
\text { exposure to patients with SARS. } \\
\text { The protective role of masks } \\
\text { suggests that in hospitals, } \\
\text { infection is transmitted by } \\
\text { droplets. }\end{array}$ \\
\hline
\end{tabular}




\begin{tabular}{|c|c|c|c|}
\hline $\begin{array}{l}\text { First author/ } \\
\text { institution } \\
\text { [ref.] }\end{array}$ & Setting & Study & Main findings and comments \\
\hline CDC [14] & USA & Guidance to the public & $\begin{array}{l}\text { Core recommendations are: 1) clean } \\
\text { your hands often; 2) avoid close } \\
\text { contact; 3) cover your mouth and } \\
\text { nose with a cloth when around } \\
\text { others; 4) cover coughs and } \\
\text { sneezes; 5) clean and disinfect. }\end{array}$ \\
\hline
\end{tabular}

COVID-19: coronavirus disease 2019; SARS-CoV-2: severe acute respiratory syndrome coronavirus 2; WHO: World Health Organization; TB: tuberculosis; MDR-TB: multidrug-resistant TB; ARI: acute respiratory infection; CDC: Centers for Disease Control and Prevention.

Controlling a respiratory infection at source using a face mask is a well-established strategy. For example, symptomatic patients with cough or sneezing are generally advised to put on a face mask, and this applies equally to patients with pulmonary tuberculosis (airborne transmission) and influenza (predominantly droplet-transmitted). With the large number of asymptomatic patients unaware of their own infection $[1,2]$, the comparable viral load in their upper respiratory tract [3], droplet and aerosol dispersion even during talking and breathing [6], and prolonged viral viability outside our body [7], we strongly advocate universal use of face masks as a means of source control in public places during the COVID-19 pandemic. Extreme forms of social distancing are not sustainable, and complete lockdown of cities or even whole countries is devastating to the economy. Universal masking in public complements social distancing and hand hygiene in containing or slowing down the otherwise exponential growth of the pandemic. Universal masking protects against cross-transmission through unavoidable person-to-person contact during the lockdown and reduces the risk for resurgence during relaxation of social distancing measures.

A high degree of compliance will maximise the impact of universal masking in public. The global shortage of surgical masks and N95 respirators is a serious concern. In line with the recent recommendation by the US Centers for Disease Control and Prevention (CDC) for healthy people to wear a cloth face cover in public [14], we strongly support the use of cloth masks as a simple, economic and sustainable alternative to surgical masks as a means of source control for general community use, so that disposable surgical masks and N95 respirators can be reserved for use in healthcare facilities. Such an intervention is likely to be life saving in many resource-limited settings.

Susanna Esposito ${ }^{1}$, Nicola Principi ${ }^{2}$, Chi Chi Leung ${ }^{3}$ and Giovanni Battista Migliori $\oplus^{4}$

${ }^{1}$ Pediatric Clinic, Pietro Barilla Children's Hospital, University of Parma, Parma, Italy. ${ }^{2}$ Università degli Studi di Milano, Milan, Italy. ${ }^{3}$ Hong Kong Tuberculosis, Chest and Heart Diseases Association, Hong Kong, China. ${ }^{4}$ Servizio di Epidemiologia Clinica delle Malattie Respiratorie, Istituti Clinici Scientifici Maugeri IRCCS, Tradate, Italy.

Correspondence: Susanna Esposito, Pietro Barilla Children's Hospital, Dept of Medicine and Surgery, University of Parma, Via Gramsci 14, 43126 Parma, Italy. E-mail: susanna.esposito@unimi.it

Received: 18 April 2020 | Accepted: 21 April 2020

Acknowledgements: The article is part of the activities of WAidid (World Association for Infectious Diseases and Immunological Disorders), the Global Tuberculosis Network (GTN) and the WHO Collaborating Centre for Tuberculosis and Lung Diseases, Tradate (ITA-80, 2017-2020-GBM/RC/LDA).

Author contributions: S. Esposito and N. Principi co-wrote the manuscript. G.B. Migliori and C.C. Leung wrote sections of the manuscript, edited the text for major intellectual components and designed the table. All authors approved the text.

Conflict of interest: None declared.

\section{References}

1 Day M. Covid-19: identifying and isolating asymptomatic people helped eliminate virus in Italian village. BMJ 2020; 368: $\mathrm{m} 1165$.

2 Day M. Covid-19: four fifths of cases are asymptomatic, China figures indicate. BMJ 2020; 369: m1375.

3 Zou L, Ruan F, Huang M, et al. SARS-CoV-2 viral load in upper respiratory specimens of infected patients. N Engl J Med 2020; 382: 1177-1179. 
4 Rothe C, Schunk M, Sothmann P, et al. Transmission of 2019-nCoV infection from an asymptomatic contact in Germany. N Engl J Med 2020; 382: 970-971.

5 World Health Organization. Modes of transmission of virus causing COVID-19: implications for IPC precaution recommendations. https://www.who.int/news-room/commentaries/detail/modes-of-transmission-of-virus-causingcovid-19-implications-for-ipc-precaution-recommendations Date last accessed: 3 April 2020.

6 Lewis D. Is the coronavirus airborne? Experts can't agree. Nature 2020; 580: 175.

7 van Doremalen N, Bushmaker T, Morris DH, et al. Aerosol and surface stability of SARS-CoV-2 as compared with SARS-CoV-1. N Engl J Med 2020; 382: 1564-1567.

8 University of Maryland. Wearing surgical masks in public could help slow COVID-19 pandemic's advance: masks may limit the spread diseases including influenza, rhinoviruses and coronaviruses." https://www.sciencedaily.com/ releases/2020/04/200403132345.htm Date last updated: 3 April 2020. Date last accessed: 3 April 2020.

9 Migliori GB, Nardell E, Yedilbayev A, et al. Reducing tuberculosis transmission: a consensus document from the World Health Organization Regional Office for Europe. Eur Respir J 2019; 53: 1900391.

10 Dharmadhikari AS, Mphahlele M, Stoltz A, et al. Surgical face masks worn by patients with multidrug-resistant tuberculosis: impact on infectivity of air on a hospital ward. Am J Respir Crit Care Med 2012; 185: 1104-1109.

11 Leung NHL, Chu DKW, Shiu EYC, et al. Respiratory virus shedding in exhaled breath and efficacy of face masks. Nat Med 2020; 26: 1-5.

12 Long Y, Hu T, Liu L, et al. Effectiveness of N95 respirators versus surgical masks against influenza: a systematic review and meta-analysis. J Evid Based Med 2020; in press [https://doi.org/10.1111/jebm.12381].

13 Seto WH, Tsang D, Yung RW, et al. Effectiveness of precautions against droplets and contact in prevention of nosocomial transmission of severe acute respiratory syndrome (SARS). Lancet 2003; 361: 1519-1520.

14 Centers for Disease Control and Prevention. Coronavirus Disease 2019 (COVID-19). How to Protect Yourself \& Others. https:/www.cdc.gov/coronavirus/2019-ncov/prevent-getting-sick/prevention.html Date last accessed: 3 April 2020

15 World Health Organization. Report of the WHO-China joint mission on coronavirus disease 2019 (COVID-19). https://www.who.int/docs/default-source/coronaviruse/who-china-joint-mission-on-covid-19-final-report.pdf Date last accessed: 1 April 2020. 